\title{
RENCANA PENATAAN KAWASAN WISATA TELAGA BIRU CISOKA, KABUPATEN TANGERANG
}

\author{
Sahda Salsabila1), Suryono Herlambang ${ }^{2)}$, Parino Rahardjo ${ }^{3)}$ \\ 1)Program Studi S1 PWK, Fakultas Teknik, Universitas Tarumanagara, sahda.345170018@stu.untar.ac.id \\ 2) Program Studi S1 PWK, Fakultas Teknik, Universitas Tarumanagara, suryonoh@ft.untar.ac.id \\ 3) Program Studi S1 PWK, Fakultas Teknik, Universitas Tarumanagara, parinor@ft.untar.ac.id
}

\begin{abstract}
Abstrak
Kawasan Wisata Telaga Biru Cisoka merupakan lahan pasca galian pasir yang menjadi tujuan destinasi wisata, yang memiliki 3 (tiga) danau dengan warna berbeda dan 1 (satu) danau sebagai Retention Basin. Kawasan Wisata Telaga Biru Cisoka memiliki potensi wisata yang berbasis agrowisata dan olahraga. Adanya tempat wisata seperti Telaga Biru Cisoka dapat menjadikan suatu daya tarik untuk memenuhi kebutuhan penduduk lokal dan menambahkan pendapatan ekonomi daerah. Maksud dan tujuan pada penelian di wisata ini yakni mengusulkan rencana penataan pada Kawasan Wisata Telaga Biru Cisoka dan mendapatkan hasil berupa masterplan Kawasan Wisata Telaga Biru Cisoka. Hal tersebut guna mengoptimalkan potensi Kawasan Wisata Telaga Biru Cisoka dan mewujudkan sebagai kawasan agrowisata dan olahraga. Kemudian menjadi masukan atau rekomendasi kepada para stakeholder yang berperan dalam perencanaan. Berdasarkan hasil analisis, Kawasan Wisata Telaga Biru Cisoka memiliki 3 (tiga) zonasi dalam rencana penataannya yakni zona air, zona pertanian, dan zona pendukung. Dimana dari masing-masing zonasi terdapat fungsi budidaya, penelitian dan edukasi, serta rekreasi. Tak hanya itu, Kawasan Wisata Telaga Biru Cisoka juga dianalisis berdasarkan kondisi alamnya, yakni berdasarkan analisis topografi dan analisis hidrologi. Dimana analisis tersebut bertujuan untuk mendapatkan fungsi dan konsep yang akan direncanakan yang sesuai dengan kondisi alam pada Kawasan Wisata Telaga Biru Cisoka.
\end{abstract}

Kata kunci : fungsi budidaya; fungsi rekreasi; hidrologi; rencana penataan; topografi

\begin{abstract}
The Telaga Biru Cisoka Tourism Area is a post-sand excavation area that is a tourist destination, which has 3 (three) lakes with different colors and 1 (one) lake as a Retention Basion. The Telaga Biru Cisoka Tourism Area has tourism potential based on agro-tourism and sports. The existence of tourist attractions such as Telaga Biru Cisoka can make an attraction to meet the needs of local residents and increase regional economic income. The purpose and objective of this research is to propose a structuring plan for the Telaga Biru Cisoka Tourism Area and get the results in the form of a Telaga Biru Cisoka Tourism Area master plan. This is in order to optimize the potential of the Telaga Biru Cisoka Tourism Area and to realize it as an agro-tourism and sports area then become input or recommendations to stakeholders who play a role in planning. Based on the results of the analysis, the Telaga Biru Cisoka Tourism Area has 3 (three) zoning in its arrangement plan, namely the water zone, agricultural zone, and service zone. Where from each zoning there are functions of cultivation, research and education, and recreation. Not only that, the Cisoka Blue Lake Tourism Area was also analyzed based on its natural conditions, like based on topographical analysis and hydrological analysis. Where the analysis aims to obtain the functions and concepts that will be planned in accordance with the natural conditions in the Cisoka Blue Lake Tourism Area.
\end{abstract}

Keywords : setup plan/ physical plan; the function of cultivation; the function of recreation; topography and hidrology 


\section{PENDAHULUAN}

\section{Latar Belakang}

Pariwisata memiliki potensi menjadi ekonomi domestic sebagai penunjang dalam suatu pendapatan daerah. Ekonomi sendiri telah dilakukan dan dikembangkan oleh setiap negara dan membuahkan hasil yang positif dalam menyerap tenaga kerja, peendapatan suatu daerah, hingga menjadi icon atau landmark dari suatu daerah tersebut. Hal ini tidak akan jauh dari suatu kualitas dan inovatif dari suatu produk yang di tampilkan. Produk tersebut perlu adanya suatu kreativitas yang tinggi dalam menciptakan produk yang berkualitas dan inovatif, maka hal ini merupakan poin penting bagi suatu wisata alam dan olahraga yang akan dikembangkan (Salman, 2010)

Suatu pembangunan wisata akan ada campur tangan dan partisipasi warga sekitar dalam rencana terhadap wisata tersebut. Hal ini dilihat dari komunitas warga lokal menjadi sumber daya yang memiliki kualitas khas, dan menjadi berperan utama dalam kegiatan tersebut. Salah satu yang mengutamakan sumber daya warga lokal dalam pembangunannya terdapat wisata alam dan agro, yang didukung dengan suatu komunitas didalamnya. Konsep ini memperlihatkan bahwa warga lokal dapat ikut terlibat langsung serta melakukan pemeliharaan untuk penataan dan pengembangan wisata tersebut, konsep ini bisa dikatakan sebagai berbasis partisipasi masyarakat lokal. Tak hanya itu warga lokal juga dapat terlibat dalam melakukan usaha untuk mendapatkan keuntungan di kawasan wisata tersebut.

Salah satu kekayaan alam yang berada di Kabupaten Tangerang terletak di Desa Cisoka, Kecamatan Cisoka. Kecamatan Tersebut Memilik luas $\pm 28,78 \mathrm{Km}^{2}$ atau sebesar $3 \%$ dari total luas keseluruhan Kabupaten Tangerang. Kemudian kekayaan alam tersebut salah satunya merupakan Objek Wisata Telaga Biru yang terletak di Dusun Cigaru, Desa Cisoka, Kecamatan Cisoka, Kabupaten Tangerang. Kawasan ini merupakan salah satu kawasan wisata bekas galian pasir. Dimana sejarahnya wisata ini terbentuk dari aktivitas manusia yang dahulu merupakan kawasan area penambangan pasir pada tahun 2006-2012. Namun telah terhenti setelah mencapai pedalaman yang tidak produktif lagi, dan kemudian tempat ini ditinggalkan dan tidak terurus. Aktivitas penambangannya ini yang tidak berkelanjutan menyisakan cekungan yang dalam menjadi 3 bagian, dengan kedalaman masing masing telaga yakni 5 20 meter. Sehingga pemilik lahan berinisiatif untuk menjadikan kawasan tersebut sebagai destinasi wisata yang berpotensi pada desa Cisoka.

Kawasan wisata Telaga Biru Cisoka ini memiliki potensi keindahan alam dan juga panorama yang indah saat sunset ataupun sunrise. Tak hanya itu, kawasan ini juga memiliki area perairan dan persawahan sebesar 10,84 Ha. Namun pada kawasan wisata Telaga Biru Cisoka belum memiliki konsep yang baik pada kawasannya, sehingga penulis bertujuan untuk menentukan konsep yang sesuai untuk wisata Telaga Biru dan juga agar wisata ini memiliki peningkatan kualitas dan daya Tarik tersendiri bagi para pengunjung. Maka pada objek penelitian untuk wisata ini, penulis akan mengusulkan pembuatan rencana penataan dan menjadi tempat destinasi wisata di desaagar wisata Telaga Biru Cisoka lebih tertata dan terawat.

\section{Rumusan Masalah}

Berdasarkan dari latar belakang, dapat digambarkan bahwa kawasan wisata Telaga Biru Cisoka memiliki rumusan masalah untuk penelitian ini, yakni Kawasan wisata Telaga Biru Cisoka tidak tertata dengan baik, serta infrastruktur dan fasilitas pendukung yang tidak memadai. Sehingga pada wisata tidak memaksimalkan pemanfaatan lahan dan perwujudan sebagai destinasi Wisata Alam (agro) dan Olahraga pada kawasan wisata Telaga Biru Cisoka. 


\section{Tujuan}

Tujuan penelitian memuat penjelasan tentang sasaran yang lebih spesifik dan hal yang menjadi tujuan penelitian yang dituangkan dalam kalimat pernyataan. Kemudian berdasarkan rumusan masalah, maka dalam penelitian ini dapat dikaitkan dengan tujuan penelitian yang akan dilakukan oleh penulis, yakni mengetahui Kondisi eksisting sarana dan prasarana, fasilitas pendukung, dan komersil yang dapat mendukung segala aspek yang masih dibutuhkan di kawasan wisata Telaga Biru Cisoka. Sehingga dapat meningkatkan kualitas wisata Telaga Biru Cisoka sebagai destinasi Wisata Alam dan Olahraga yang memiliki perpaduan fungsi. Dengan akhir penelitian dapat membuat usulan konsep Masterplan terhadap pemanfaatan lahan wisata pada Telaga Biru Cisoka yang tepat dan sesuai, agar dapat meningkatkan kualitas dan daya Tarik wisata tersebut

\section{KAJIAN LITERATUR}

\section{Pemanfaatan Lahan Bekas Galian Pasir}

Menurut Sabri (2015), pemanfaatan kolong dapat dijadikan beberapa hal yang dipergunakan yaitu sebagai berikut; a) Kolong sebagai sumber air baku, b) Kolong sebagai budidaya ikan air tawar, c) Kolong sebagai sarana rekreasi dan wisata air, seperti pemanfaataan kolam renang, dan olahraga air. Sehingga dapat menjadi daerah wisata. (Mahara, 2011)

\section{Agrowisata}

Menurut Sutjipta (2001), Agrowisata dapat dikatakan memiliki sistem dalam kegiatannya, dimana kegiatan tersebut terkoordinasi dalam suatu pengembangan wisatanya. Kegiatan yang dapat dikembangkan dalam agrowisata yakni, perikanan, pertanian, dan perkebunan yang bertujuan untuk meningkatkan pelestarian lingkungan pada kawasan tersebut dan juga untuk meningkatkan kesejahteraan masyarakat local yang bekerja sebagai petani.

\section{Kawasan Zonasi Wisata}

Menurut Musanef (2017), Adanya zonasi wisata bertujuan untuk menjaga ekosistem agar tetap terjaga, yang didalamnya turut serta dalam menjaga lingkungan agar berkelanjutan. Zonasi wisata ini dibutuhkan pada wisata berbasis alam bertujuan untuk usaha dalam pengurangan dampak kerusakan yang mungkin terjadi akibat adanya kunjungan dari para wisatawan. Zonasi ini berfungsi untuk dilakukan pembagian wisatawan, agar wisatawan tidak menumpuk di satu tempat saja, yang dapat mengakibatkan berkurangnya kenyamanan wisatawan

\section{Pariwisata Community Based Tourism}

Menurut UNEP dan WTO (2005), terdapat 10 prinsip dasar CBT yang digunakan sebagai tool of community development bagi masyarakat lokal, yakni sebagai berikut; a) Mengakui, mendukung dan mengembangkan kepemilikan lokal dalam industri pariwisata, b) Mengikutsertakan anggota masyarakat dalam memulai setiap aspek, c) Mengembangkan kebanggaan masyarakat lokal, d) Mengembangkan kualitas hidup masyarakat lokal, e) Menjamin keberlanjutan lingkungan, f) Mempertahankan keunikan karakter dan budaya lokal, g) Membantu berkembangnya pembelajaran tentang pertukaran budaya pada masyarakat, h) Menghargai perbedaan budaya dan martabat manusia.

\section{Partisipatif Masyarakat}

Menurut Riskayana, dkk. (2018). Suatu partisipatif saling berhubungan dengan masyarakat yang tidak lagi diposisikan sebagai seorang yang hanya menerima suatu keputusan dari pemerintah, namun masyarakat dapat berperan aktif dalam pengambilan keputusan dan pasti terlibat dalam suatu kerangka untuk mengembangkan pariwisata. 


\section{Topografi}

Menurut Heywood (2002), kontur merupakan suatu garis yang berada pada peta lahan kemiringan atau kelerangan dari suatu kawasan. Dimana garis tersebut saling menghubungkan antara titik tertinggi, titik sedang, dan titik terendah dari ketinggian suatu kawasan. Hal ini biasanya dimanfaatkan bagi para peneliti untuk mengetahui bentuk daripada suatu permukaan bumi.

\section{Hidrologi}

\section{a. Curah Hujan dan Run Off}

Dalam Apriani, dkk. (2013), Analisis Intensitas Curah Hujan dapat di hitung dengan metode berdasarkan rumus Dr. Mononobe dari Kensaku Takeda (2006), sebagai berikut :

$$
I=\frac{\mathrm{R}_{24}}{24}\left(\frac{24}{\mathrm{t}}\right)^{\frac{2}{3}}
$$

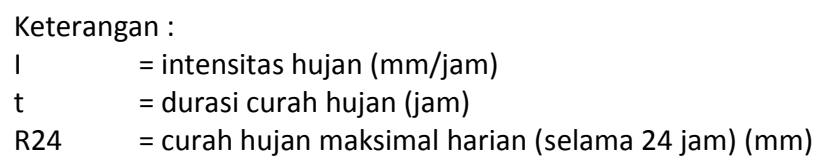

Sedangkan Run Off dapat diartikan yaitu air larian, pada penelitian ini yaitu untuk mengetahui perhitungan dan area mana saja yang dapat dijadikan run off berdasarkan kemiringan atau kelerengannya. Atau suatu volume air yaitu aliran langsung, dimana jumlah volume aliran air tanah dari tiap lapisan air tanah di akhir tiap interval waktu. Jika intensitas curah hujan melebihi laju infiltrasi, maka kelebihan air akan menjadi cadangan air di permukaan. Namun bila kapasitas cadangan melampaui batas permukaan, maka limpasan air tersebut akan bergerak ke area yang lebih rendah.

\section{b. Debit Mata Air}

Perhitungan debit mata air pada penelitian saat ini menggunakan metode tampung, dimana metode ini merupakan pembuktian dari Streeter Phelps. Dalam Noviana (2018), dimana cara perhitungan metode tampung, yakni menggunakan 1 buah botol plastic dengan bantuan stopwatch. Metode ini biasanya digunakan pada mata air yang dapat mengalir.

\section{c. Kapasitas Danau dan Garis Sempadan Danau}

Berdasarikan penetapan Peraturan Menteri Pekerjaan Umum dan Perumahan Rakyat Republik Indonesia Nomor 28/PRT/M/2015, tentang Penetapan Garis Sempadan Sungai dan Garis Sempadan Danau. Sempadan danau berfungsi sebagai upaya agar kegiatan yang dilakukan pada rencana suatu kawasan dapat terlaksana dan upaya agar danau tersebut tidak mengalami kerusakan akibat adanya suatu pengemabnagn pada area danau. Kemudian berdasarkan Kementrian PU pada Ketetapan pada Nomor 28/PRT/M2015 menjelaskan tentang Garis Sempadan Danau ditetapkan mengelilingi danau paling sedikit berjarak 50 meter dari tepi muka air tertinggi yang pernah terjadi. Namun pada pasal 18 ayat 2, menjelaskan bahwa penetapan garis sempadan danau dilakukan berdasarkan pola pengelolaan sumber daya air dan harus mempertimbangkan karakteristik danau, kondisi sosial budaya, masyarakat setempat, dan kegiatan operasi pemeliharaan danau. Kemudian menurut pasal 23 , ayat 1 sempadan danau hanya dapat dimanfaatkan untuk kegiatan dan bangunan tertentu. Seperti kegiatan penelitian dan pengembangan ilmu pengetahuan, pariwisata, olahraga, aktivitas budaya, dan keagamaan.

\section{d. Kapasitas Drainase}

Berdasarkan peraturan Kementerian Pekerjaan Umum, telah ditetapkan bahwa ukuran jaringan drainase yakni memiliki ketinggian $40 \mathrm{~cm}$, dengan kemiringan $2 \%$ dan memiliki diameter atau lebar dalam sebesar $20 \mathrm{~cm}$. 


\section{e. Kualitas Air}

Menurut Saiful (2016), Kualitas air sendiri dapat digolongkan menjadi beberapa bagian, dan masing - masing golongan tersebut memiliki peruntukan sendiri. Berkut dibawah ini merupakan penjabaran mengenai golongan kualitas air, sebagai berikut; a) Kelas I : Air baku air minum atau peruntukan yang setara, b) Kelas II : air baku untuk saran dan prasarana rekreasi air, pembudidayaan ikan air tawar, peternakan, dan dapat menjadi pengirigasian pertanaman atau pertanian atau peruntukan lainnya, c) Kelas III : Air baku untuk pembudidayaan ikan air tawar, peternakan, air untuk mengairi pertanaman/peruntukan lain yang setara, d) Kelas IV : Air baku untuk mengairi pertanaman/peruntukan lain yang setara

\section{f. Evapotranspirasi}

Evapotranspirasi dapat dikatakan sebagai penguapan air pada daera atau kawasan tertentu, diaman evapotranspirasi biasanya berada di area ruang terbuka hijau dan area ruang terbuka biru. Perhitungan evapotranspirasi dapat dihasilkan berdasarkan proses respirasi dan fotosintesis. Dalam Prachmayandini, dkk. (2012), perhitungan evapotranspirasi pada penelitian ini menggunakan metode dari Blaney - Criddle, dimana metode ini perhitungan yang sederhana guna menghitung berbagai tanaman berdasarkan suhu, jumlah jam siang hari, dan koefisien tanaman empiris dimana biasanya digunakan pada daerah yang beriklim kering dan sedang. Berikut dibawah ini merupakan perhitungan berdasarkan metode Blaney - Criddle, sebagai berikut :

\section{$E T o=p(0,46 . T m e a n+8,13)$}

Keterangan :

$\mathrm{P} \quad=$ persentase harian siang hari, rata rata tahunan

Tmean = suhu harian rata rata

\section{g. Kebutuhan Air Sawah}

Kebutuhan air sawah, jika diperlukannya suatu irigasi yang baik pada suatu kawasan wisata yang berbasis pertanian dan perkebunan. Maka hal ini melakukan perhitungan dengan teori dari Fuadi (2016), Perlu diketahui padi akan siap panen bekisar $3-4$ bulan. Dimana tahap awal penanaman memerlukan pengirigasian air terlebih dahulu. Teori mengatakan kebutuhan air sawah sebesar 0,74-1,2 Liter/detik/Ha, atau 7,2 Liter/menit, dan 432 Liter/Jam.

\section{h. Retention Basin}

Retention basin dibutuhkan saat terjadinya suatu over flow terhadap air yang melebih kapasitas daya tampungnya. Dimana over flow yang dimaksud dalam penelitian ini merupakan banjir danau atau tampungan, yang berarti naiknya mua air di danau atau tampungan hingga melewati tanggul atau batas tertentu yang telah ditetapkan (Harmani: 2017).Hal ini terjadi akibat intensitas hujan yang tinggi, dimana mengakibatkan danau atau tampungan tidak mampu menahan kapasitas air yang melebihi batasnya. Sehingga terjadi banjir atau genangan di daerah sekitarnya.

\section{METODE PENELITIAN}

Penelitian ini menggunakan pendekatan kualitatif dengan metode deskriptif analisis yang menggunakan pendeskripsian partisipatif dalam rencana penataan Kawasan Wisata Telaga Biru Cioska, untuk menjadi pariwisata yang berkelanjutan.

Lokasi Penelitian Kawasan Wisata Telaga Biru Cisoka terletak di Kabupaten Tangerang, Kecamatan Cisoka, Desa Cisoka, tepatnya di Dusun Cigaru. Objek Wisata ini memiliki luas \pm 10,84 Ha. Batas wilayah, sebagai berikut; a) Sebelah Utara; Desa Caringin, b) Sebelah Timur: 
Desa Jeunjing, c) Sebelah Barat : Desa Sukatani, d) Sebelah Selatan : Kecamatan Solear.

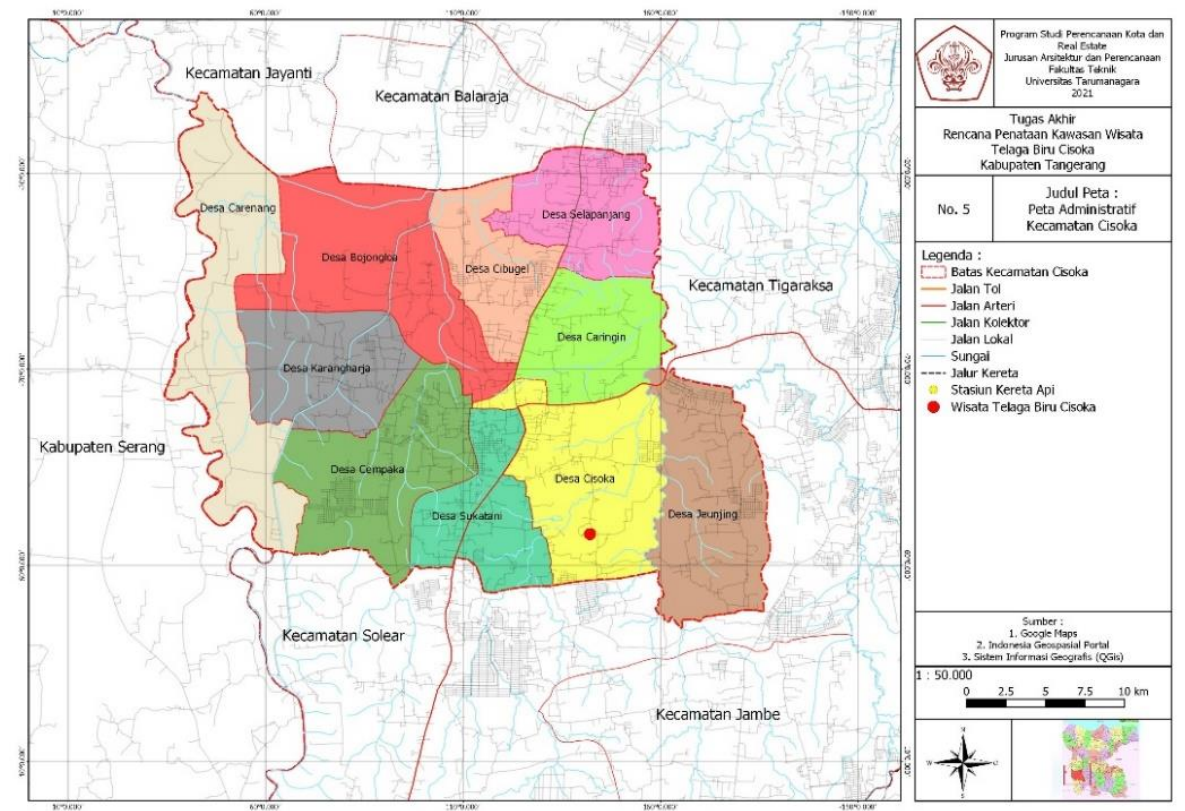

Gambar 1. Peta Letak Lokasi Wisata Terhadap Kecamatan Cisoka Sumber : Hasil Olahan Penulis

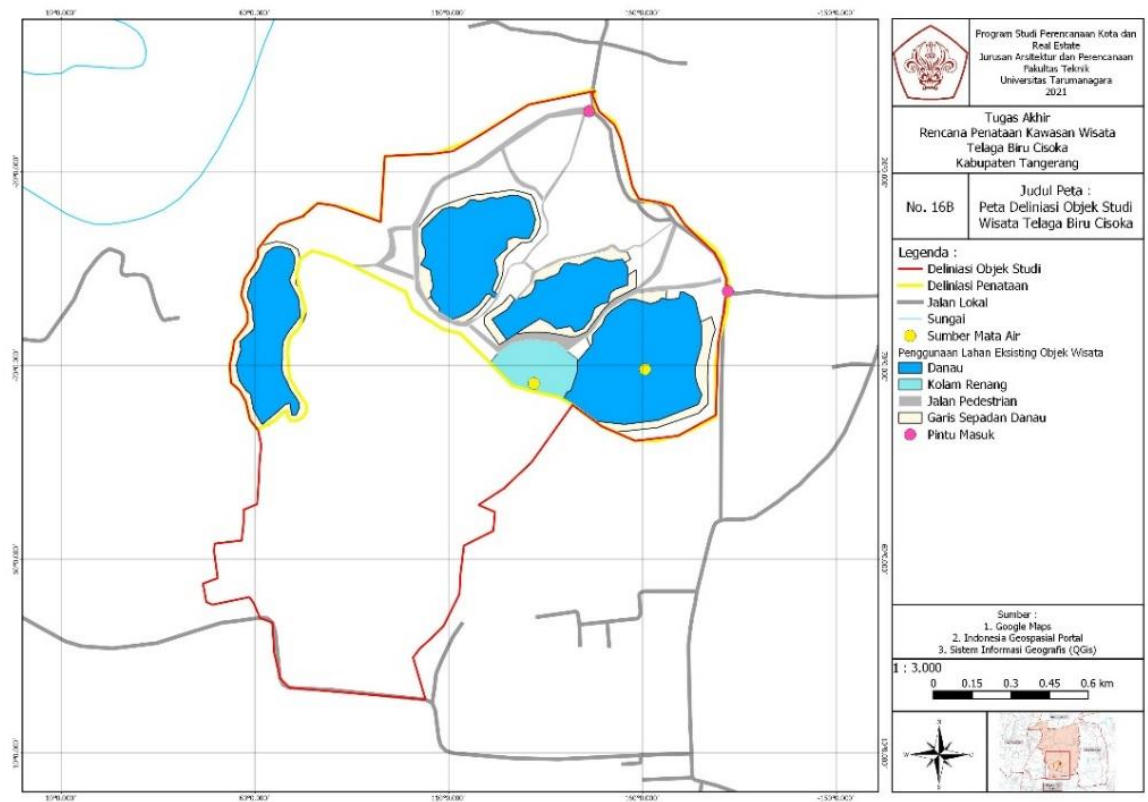

Gambar 2. Peta Batas Deliniasi Kawasan Wisata Telaga Biru Cisoka Sumber : Hasil Olahan Penulis

Metode Penelitian yang dilakukan pada penelitian di Kawasan Wisata Telaga Biru Cisoka yakni dengan penelitian secara kualitatif. Dimana penelitian kualitatif dilakukan dengan cara sebagai berikut : a) Observasi lapangan, b) In-Depth-Inteview, dan c) dokumentasi. Dalam menentukan narasumber, penulis melakukan wawancara dengan metode purposive sampling untuk mendapatkan narasumber. Narasumber tersebut terdiri atas; a) Pak Andi sebagai pengelola wisata, b) Pak Dodi sebagai ketua komunitas pokdarwis, b) pedagang local dan masyarakat local, serta d) Ibu Nurbaiti, Ibu Nani, dan Pak Jaka selaku pegawai Disporabudpar. 


\section{DISKUSI DAN HASIL}

\section{Analisis Kebijakan}

Dalam analisis ini membahas Kebijakan RTRW Kabupaten Tangerang 2011 - 2031. Pada objek wisata Telaga Biru Cisoka, merupakan kawasan permukiman sedang. Kemudian berdasarkan pola ruang objek ini merupakan, kawasan budidaya dengan hunian rendah, pertanian, dan mempertahankan kawasan resapan. Namun kebijakan yang seharusnya dibuat tidak hanya mengenai tata ruang saja, tetapi minimal oleh Disporabudpar Kabupaten Tangerang mengenai pariwisata untuk menjadi landasan bagi objek wisata Telaga Biru Cisoka terlaksana Padahal perlu diketahui bahwa Kabupaten Tangerang telah memiliki aturan mengenai aturan desa dan kebijakan pendanaan. Namun, dalam kenyataannya hal tersebut belum dilaksanakan pada Desa Cisoka dan belum memiliki peraturan desa yang mendetail.

\section{Analisis Lokasi dan Tapak}

1. Lokasi

Pada analisis Lingkungan sekitar, penggunaan lahan pada zona pertanian dan perkebunan memiliki $73 \%$ dari total seluruh luas desa. Sehingga zona pertanian dan perkebunan yang ada masih dikategorikan luas pada Desa Cisoka tersebut, dan terdapat potensi yang baik bagi pengembangan wwisata desa. Sehingga, perlu adanya kebijakan baru terhadap potensi wisata di wilayah ini. Tak hanya itu Berdasarkan hasil analisis proximity tersebut, Wisata Telaga Biru cenderung dekat dengan pusat kegiatan di sekitarnya. Namun dalam transportasi terdapat permasalahan, perlu adanya konektivitas moda transportasi untuk penunjang bagi para pengunjung jika mendatangi lokasi dengan menggunakan transportasi umum.

\section{Tapak}

Berdasarkan penggunaan lahan eksisting, lahan terbesar area lahan yang pasif dimanfaatkan dan tidak digunakan secara maksimal yaitu area lahan kosong, sebesar $28 \%$. Hal tersebut mengakibatkan wisata ini menjadi terlihat tidak terawat dan tidak tertata dengan baik. Tak hanya itu kondisi pada jalan internal tidak cukup baik. Kondisi yang ada sangat berbatu dan cukup membahayakan jika para pengunjung mendatangi area tersebut. Namun untuk lebar jalan, sudah terlihat lebar yakni sekitar 2 - 3 meter. Sehingga analisis ini membuktikan bahwa perlu adanya perencanaan kembali pada objek wisata Telaga Biru ini.

\section{Analisis Topografi, Hidrologi, kondisi alam}

Berdasarkan kontur pada Kawasan Wisata Telaga Biru Cisoka,terlihat bahwa kontur di kawasan tersebut dikategorikan landai dimana interval yang digunakan yakni sekitar 1 meter. Terlihat pada peta bahwa tidak ada perubahan yang signifikan terhadap ketinggian tanah yang berada di Kawasan Wisata Telaga Biru Cisoka, yakni sekitar $23 \mathrm{Mdpl}-38 \mathrm{Mdpl}$.

Intensitas Curah Hujan pada area tersebut sebanyak 17,50 mm/jam. Dimana Perhitungan evapotranspirasi; diketahui luas lahan yang dimungkinkan terjadinya run off ke arah wisata yakni 1,2 Ha. Maka perhitungan evapotranspirasi didapat sebanyak, 1,108 mm/jam. Lalu Perhitungan debit run off; diketahui Luas asumsi run off $\mathrm{x}$ (intensitas curah hujan evapotrasnpirasi) $=120.000 \mathrm{~m} 2 \times 0,016391=1920 \mathrm{m3} / \mathrm{jam}$. Dan diketahui Perhitungan debit mata air, yakni; sumber mata air tersebut sebanyak 1.5 Liter/4 Detik atau setara dengan 0.375 Liter / detik. => 1.350 liter/jam $(1,35 \mathrm{~m} 3 / \mathrm{jam})$. Sehingga dapat air yang didapat 1.921,35 m3 perjam. Apabila danau A,B,C overcapacity. maka danau D sebagai Retention Basin akan menampung. Namun jika danau $D$ mengalami over capacity juga, maka terdapat saluran drainase yang mengarah ke sungai Cidurian- Cimanceuri.

Lalu berdasarkan kondisi alam, telah dilakukan uji labolatorium terhadap perairan pada Kawasan Wisata Telaga Biru Cisoka, yakni a) Kualitas Mata Air memiliki pH 6,25, b) Kualitas Air Danau A memiliki pH 7,38, c) Kualitas Air Danau B memiliki pH 7,20, d) Kualitas Air Danau 
$\mathrm{C}$ memiliki pH 7,20. Berdasarkan analisis diatas, perlu diketahui pH air yang dapat dikonsumsi manusia yakni antara $6-8,5$. kualitas seluruh perairan dapat dikonsumsi dengan baik

\section{Analisis Faktor Penghambat}

Menurut hasil wawancara dari pihak pengelola, faktor utama dalam suatu perencanaan wisata merupakan pendidikan. Masyarakat desa Cisoka memang mengikuti dan berpartisipasi dalam wisata ini, namun masih kurangnya bimbingan dan penjelasan mengenai wawasan dalam pengembangan wisata Telaga Biru ini. Dalam teori pariwisata, pendidikan menjadi faktor dalam suatu rencana pengembangan, sehingga hal ini menjadi mutlak dapat mempengaruhi kecenderungan masyarakat dalam berpartisipasi. Maka disini perlu adanya bimbingan terhadap masyarakat yang ikut dalam berpartisipasi dalam rencana pengembangan yang akan dilakukan.

Faktor kedua dalam suatu perancaan wisata yakni pendanaan. Hal ini dapat terlihat dari kondisi fisik wisata Telaga Biru yakni terlihat sangat tidak terawat dan banyak dari wahana yang sudah tidak layak di gunakan kembali. Tak hanya itu pengunjung berkurang jauh dari tahun 2019, hal tersebut sepenuhnya tidak mencukupi untuk pengelolaan dan rencana pengembangan Wisata Telaga Biru ini. Sehingga perlu adanya dana bantuan dari pemerintah kabupaten maupun pemerintah desa, seperti yang tertera pada peraturan yang telah berlaku dan yang digunakan.

\section{Analisis Permasalahan dan Potensi Utama}

Dari analisis yang telah dilakukan mencakup seluruh faktor, terdapat enam permasalahan utama yang ada pada Kawasan Wisata Telaga Biru Cisoka. Permasalahan yang paling mendesak atau utama, dijabarkan secara berurutan yakni pertama mempertahankan 4 Danau yang menjadi objek wisata, terdiri atas Danau A, Danau B, Danau C, Danau D. kemudian yang kedua yakni mempertahankan bentang alam dan lanskap, ketiga penggunaan lahan eksisting yang tidak sesuai dengan perlindungan alam, keempat pengolahan dan pembuangan jaringan drainase dan limbah, kelima penataan ulang terhadap fasilitas pendukung dan Infrastruktur, serta keenam kerjasama pengelolaan antar stakeholder.

Kemudian dari seluruh permasalahan utama yang ditemukan, akan diselesaikan dengan penyusunan konsep terhadap Kawasan Wisata Telaga Biru Cisoka dengan hasil berupa Masterplan pada kawasan tersebut. Berikut dibawah ini penjabaran mengenai enam permasalahan dan potensi utama pada Kawasan Wisata Telaga Biru Cisoka, sebagai berikut :

\section{a. Mempertahankan Empat Danau atau Telaga yang menjadi objek wisata}

Permasalahan dan potensi pertama pada Kawasan Wisata Telaga Biru Cisoka yakni terdapat empat Danau yang menjadi objek wisata, terdiri dari Danau A, Danau B, Danau C, dan Danau D. Berikut dibawah ini merupakan penjabaran mengenai permasalahan dan potensi yang ada pada setiap danau yang menjadi objek pada Kawasan Wisata Telaga Biru Cisoka, sebagai berikut.

\section{Danau A}

Danau A, merupakan danau yang memiliki keunikan tersendiri. Yakni memiliki titk mata air yang berada di tengah danau tersebut, dimana memiliki ukuran danau $\pm 7,983 \mathrm{~m} 2$ dengan kedalaman \pm 5 meter. Dikarenakan danau A memiliki mata air, maka tidak boleh adanya bangunan yang berada di tengah danau agar kelestarian mata air tidak mengalaim kerusakan. Namun, pada kondisi eksisting terdapat aktivitas berupa wahana permainan, berupa permainan bebek - bebekkan, getek cinta yang dapat menyebrang ke area air mancur yang berada di sebrang danau, dan wisata outbound, serta pada garis sempadan danau terdapat rumah pintar cigaru. 


\section{Danau B}

Danau B, merupakan danau kedua yang memiliki potensi wisata berupa warna air berwarna hijau kebiru - biruan dengan pemandangan yang menarik di danau tersebut, memiliki ukuran danau $\pm 3,376 \mathrm{~m} 2$ dengan kedalaman \pm 15 meter. Tak hanya itu, para pengunjung dapat bermain wahana getek cinta yang telah di sediakan. Namun pada area garis sempadan danau perlu diperhatikan penggunaannya, agar danau B tidak mengalami kerusakan.

\section{Danau C}

Danau C, merupakan danau ketiga yang memiliki potensi wisata berupa warna air berwarna biru tosca dengan pemandangan yang menarik di danau tersebut, memiliki ukuran danau \pm $5,177 \mathrm{~m} 2$ dengan kedalaman \pm 20 meter. Tak hanya itu, para pengunjung dapat bermain wahana getek cinta yang telah di sediakan. Namun pada area garis sempadan danau perlu diperhatikan penggunaannya, agar danau $\mathrm{C}$ tidak mengalami kerusakan.

\section{Danau D}

danau D, merupakan danau keempat yang memiliki potensi sebagai area Retention Basin pada kawasan wisata ini, danau ini memiliki ukuran $\pm 11,200 \mathrm{~m} 2$ dengan kedalaman \pm 3 meter. Danau ini menjadi fungsi sebagai Retention Basion sekaligus area wisata bagi para pengunjung. Namun pada area garis sempadan danau perlu diperhatikan penggunaannya, agar danau $\mathrm{C}$ tidak mengalami kerusakan. Rentention Basin sendiri merupakan digunakan sebagai tampungan dari aliran air hujan dan wadah sebagai aliran air yang mengalami overflow dari danau $A$, danau $B$, dan danau $C$. serta pada danau $D$ ini juga dapat dijadikan wadah perairan bagi area sawah untuk irigasi, hal ini guna untuk melestarikan danau $A$, danau $B$, dan danau $C$ dari pengambilan air oleh para petani.

Konsep dan rencana pada Masterplan Kawasan Wisata Telaga Biru Cisoka diharapkan menjadi landasan dan perlindungan yang kuat untuk program pelestarian kondisi alam. Sehingga pada konsep dan rencana dapat mempertahankan keempat danau atau telaga pada Kawasan Wisata Telaga Biru Cisoka, sebagai objek wisata dan ODTW. Tak hanya itu, dapat mempertahankan penggunaan lahan air yang memiliki lanskap alami dapat diarahkan untuk memenuhi persyaratan yang mendukung program pelestarian dan perlindungan alam.

\section{b. Mempertahankan Bentang Alam dan Lanskap}

Potensi kedua pada Kawasan Wisata Telaga Biru Cisoka yakni kondisi lanskap yang masih alami berupa area persawahan. Kegiatan masyarakat desa lokal bergantung pada area persawahan tersebut, dimana masyarakat lokal didominasikan sebagai petani. Sehingga area persawahan tersebut menjadi sumber perekonomian dan warga lokal sangat bergantung pada pengelolaan pelestarian lanskap alami ini. Konsep dan rencana pada Masterplan Kawasan Wisata Telaga Biru Cisoka diharapkan menjadi landasan dan perlindungan yang kuat untuk program pelestarian kondisi alam. Dimana setiap meningkatnya intensitas aktivitas dan penggunaan lahan yang memiliki lanskap alami dapat diarahkan untuk memenuhi persyaratan yang mendukung program pelestarian dan perlindungan alam.

\section{c. Penggunaan Lahan Eksisting yang Tidak Sesuai dengan Perlindungan Alam}

Pada Kawasan Wisata Telaga Biru Cisoka terdapat penggunaan lahan eksisting yang tidak sesuai dengan perlindungan alam. Hal ini memerlukan rencana mengenai penggunaan lahan eksisting yang disesuaikan dengan kondisi alamnya. Rencana penggunaan lahan yang dilakukan diharapkan dapat sesuai dengan program pelestarian dan pelindungan alam. Pada program pelestarian dan pelindungan alam jika sesuai berdasarkan kondisi eksisting, dapat terbagi pada aspek zona air, zona pertanian, dan zona pendukung. Sehingga apabila terdapat zonasi atau bangunan yang tidak sesuai dan tersebar, maka dalam perencanaan yang direncanakan akan disatukan pada zona yang telah ditetapkan. 


\section{d. Pengelolaan dan Pembuangan Jaringan Drainase dan Limbah}

Pada Kawasan Wisata Telaga Biru Cisoka memerlukan rencana mengenai pengelolaan dan pembuangan jaringan drainase dan limbah, hal ini dikarenakan Kawasan Wisata Telaga Biru merupakan wisata perairan yang membutuhkan jaringan drainase. Tak hanya itu pengelolaan limbah berupa padat dan cair, yang dapat menjadi permasalahan dalam rencana penataan. Pada tingkat teknis, jaringan drainase sangat dibutuhkan dalam pelestarian kualitas alam dan danau. Tak hanya itu jaringan drainase perlu direncanakan berdasarkan kontur dan berakhir pada aliran sungai yang terdekat.

Demikian juga pengolahan limbah, penanganan sampah tidak dapat dilakukan secara konvensional dalam penanganannya. Hal tersebut dilakukan guna terbentuknya kelestarian alam alami pada kondisi eksisting Kawasan Wisata Telaga Biru Cisoka. Tumpukan dari aktivitas rekreasi dan pengunjung di area wisata perlu dikelola dan diarahkan agar tidak menggangu kelestarian alam yang menjadi potensi objek wisata di Kawasan Wisata Telaga Biru Cisoka. Dalam rencana pengolahan limbah perlu adanya partisipatif berbagai pihak yang telah ada, yakni Warga Lokal, Pengelola wisata, Komunitas Pokdarwis, dan pengunjung. Konsep inovatif yang dapat dilakukan yaitu, zero waste, dan material kemasan lingkungan.

Pembuatan masterplan dan rencana peta jaringan drainase dan limbah, diharapkan mendorong dan mendukung terwujudnya pengolahan jaringan drainase dan limbah, yang ramah lingkungan bagi kondisi alam yang alami.

\section{e. Penataan Ulang terhadap Infrastruktur dan Fasilitas Pendukung}

Pada Konsep Penataan Ulang terhadap Infrastruktur dan Fasilitas Pendukung, hal ini terfokus pada struktur jalan, kondisi fisik wisata dan fasilitas pendukung bagi wisatawan. Hal ini dapat dilihat bahwa infrastruktur dan fasilitas pendukung pada kawasan wisata sangat tidak mendukung.

Konsep dan pembuatan masterplan diharapkan dapat menyusun penataan infrastruktur dan fasilitas yang mendukung bagi para pengunjung, seperti kondisi jaringan jalan mikro, fasilitas pendukung untuk para pengunjung, dan menghubungkan antar zona satu ke zona lainnya. Sehingga penataan ulang ini dapat menjadi integrasi sebagai dasar struktur ruang pada Kawasan Wisata Telaga Biru Cisoka

\section{f. Kerjasama Pengelolaan antar Stakeholder}

Permasalahan terakhir pada Kawasan Wisata Telaga Biru Cisoka yakni kerjasama pengelolaan antar stakeholder, hal ini perlu adanya rencana mengenai peran dan preferensi antar stakeholder. Sehingga apabila kerjasama pengelolaan yang dilakukan antar stakeholder dapat dilakukan secara optimal. Berdasarkan analasisi peran dan preferensi antar stakeholder, dimana terdapat empat stakeholder yang berperan penting dalam pengelolaan kawasan Wisata Telaga Biru Cisoka, yakni pemilik dan pengelola, masyarakat lokal, ketua pokdarwis, dan pihak pemerintah. Keempat stakeholder harus saling berkomunikasi dalam perencanaan dan pengelolaan bagi Kawasan Wisata Telaga Biru Cisoka.

\section{g. Konsep dan Rencana}

\section{Tiga Lapis Konsep Program Ruang pada Kawasan Wisata Telaga Biru Cisoka}

Sehingga berdasarkan Permasalahan dan Potensi pada Kawasan Wisata Telaga Biru Cisoka, dapat direncanakan tiga lapis konsep program ruang yang terdiri atas zona air, zona pertanian dan zona pendukung. Pembagian pada Kawasan Wisata Telaga Biru Cisoka terbagi menjadi tiga bagian program ruang, sebagai berikut :

\section{Zona Air}


Pada zona ini dapat dikategorikan sebagai kawasan yang berfungsi untuk mempertahankan bentuk dan ciri khas yang ada pada Kawasan Wisata Telaga Biru Cisoka dan menjadi Objek Destinasi Tujuan Wisata (ODTW) dari kawasan wisata ini. Disini pihak pengelola mempertahankan dengan membuat suatu tanda dan wisata air untuk para pengunjung. Pada Kawasan Wisata Telaga Biru Cisoka ini zona inti mempunyai luas sebesar5.667 ha. Tak hanya itu, zona air ini membuat unik pada wisata ini merupakan terdapat sumber mata air yang dimanfaatkan menjadi area wisata air. dan menjadi area atraksi pada Kawasan Wisata Telaga Biru Cisoka.

\section{Zona Pertanian dan Perkebunan}

Pada zona pengembangan ini memiliki fungsi sebagai area yang dikembangkan yang diperuntukan menjadi potensi bentang alam dan lanskap, dimana area ini dapat menjadi area rekreasi atau kegiatan yang direncanakan dalam pengembangan berupa kegiatan pertanian dan perkebunan. Zona pertanian yang menjadi pengembangan direncanakan memiliki luas sebesar 5,089 Ha.

\section{Zona Pendukung}

Pada zona pendukung ini menjadi area sebagai fungsi untuk suatu pelayanan dari aktivitas dan kegiatan berupa fasilitas bagi para pengunjung. Sehingga fasilitas tersebut menjadi pendukung bagi terwujudnya kegiatan yang direncanakan pada Kawasan Wisata Telaga Biru Cisoka. Dimana area pelayanan ini dapat terdiri atas sarana dan prasarana, fasilitas pendukung, zona komersial seperti akomodasi, pusat perbelanjaan, tempat makan, toilet, dan sebagainya. Zona ini memiliki luas 0,578 $\mathrm{Ha}$.

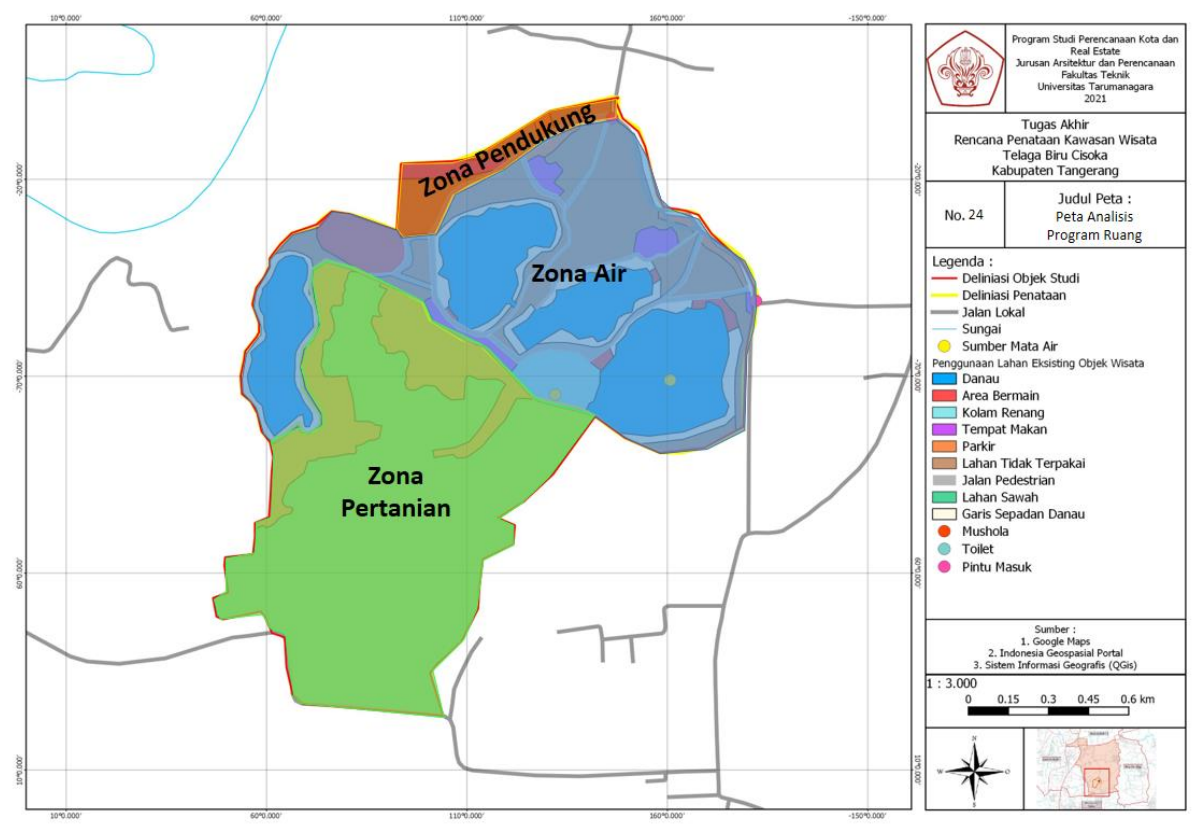

Gambar 3. Peta Analisis Program Ruang (Rencana Konsep)

Sumber : Hasil Olahan Penulis 
Tabel 1. Rencana Konsep pada Kawasan Wisata Telaga Biru Cisoka

\begin{tabular}{|c|c|c|}
\hline Zonasi & Konsep & Detail Konsep \\
\hline $\begin{array}{l}\text { Lapis } 1 \\
\text { Zona Air }\end{array}$ & Wisata Alam dan Air & $\begin{array}{l}\text { Rekreasi dan olahraga (Outbound) bagi dewasa } \\
\text { dan anak anak. } \\
\text { Detail Konsep : } \\
\text { Arahan sebagai ODTW, perlu pengaturan lebih } \\
\text { detail mengenai penggunaan lahan, intensitas } \\
\text { kegiatan, persyaratan bangunan, pengelolaan } \\
\text { lingkungan dan sistem drainase. }\end{array}$ \\
\hline $\begin{array}{c}\text { Lapis } 2 \\
\text { Zona Pertanian }\end{array}$ & Agrowisata & $\begin{array}{l}\text { Wisata Pertanian dan Perkebunan bagi keluarga. } \\
\text { Detail konsep : } \\
\text { Arahan sebagai pengembangan kegiatan wisata, } \\
\text { infrastruktur yang tidak merusak alam, ruang } \\
\text { terbuka publik, jalur mobilitas non motor, } \\
\text { pengelolaan sistem drainase }\end{array}$ \\
\hline $\begin{array}{c}\text { Lapis } 3 \\
\text { Zona Pendukung }\end{array}$ & $\begin{array}{c}\text { Zona aktivitas, } \\
\text { fasilitas pendukung, } \\
\text { dan akomodasi }\end{array}$ & $\begin{array}{l}\text { Pusat Perbelanjaan dan Fasilitas Pendukung. } \\
\text { Detail konsep : } \\
\text { arahan sebagai area fasilitas pendukung bagi } \\
\text { pengunjung, pengembangan fungsi komersial, } \\
\text { dan tempat akomodasi wisata. }\end{array}$ \\
\hline
\end{tabular}

Sumber : Hasil Olahan Penulis

Tabel 2. Rencana Konsep Sarana dan Prasarana pada Kawasan Wisata Telaga Biru Cisoka

\begin{tabular}{|c|c|c|c|}
\hline Zonasi & Kondisi Eksisting & Sarana dan Prasarana & Fasilitas Pendukung \\
\hline Zona Air & $\begin{array}{l}\text { Danau A, Danau B, Danau } \\
\text { C, Danau D, Kolam } \\
\text { Renang, Budidaya } \\
\text { Perikanan, Wahana } \\
\text { Permainan, dan Outbound }\end{array}$ & $\begin{array}{c}\text { Pedestrian, Track Bike, } \\
\text { Jaringan Drainase, } \\
\text { Penerangan Jalan, } \\
\text { TPS, Air Bersih, View } \\
\text { Deck }\end{array}$ & $\begin{array}{c}\text { Toilet } \\
\text { Tempat Pemancingan } \\
\text { Menara pandang } \\
\text { Gazebo }\end{array}$ \\
\hline $\begin{array}{l}\text { Zona } \\
\text { Pertanian dan } \\
\text { Perkebunan }\end{array}$ & $\begin{array}{c}\text { Agrowisata } \\
\text { RTH }\end{array}$ & $\begin{array}{c}\text { Pedestrian, Track Bike, } \\
\text { Penerangan Jalan, } \\
\text { Jaringan Drainase, Air } \\
\text { bersih, TPS }\end{array}$ & $\begin{array}{c}\text { Pos Keamanan dan Kesehatan, } \\
\text { Toilet, Warung, Gazebo, Area } \\
\text { Parkir Sepeda }\end{array}$ \\
\hline $\begin{array}{c}\text { Zona } \\
\text { Pendukung }\end{array}$ & $\begin{array}{l}\text { Aktivitas Fasilitas } \\
\text { Pendukung }\end{array}$ & $\begin{array}{c}\text { Pedestrian, Track Bike, } \\
\text { Penerangan jalan, } \\
\text { Jaringan drainase, Air } \\
\text { bersih, TPS }\end{array}$ & $\begin{array}{c}\text { Pusat Informasi, Area, parkir } \\
\text { kendaraan, Area parkir sepeda, } \\
\text { ATM, Toilet, Foodcourt, Pusat } \\
\text { Souvenir, Mushola }\end{array}$ \\
\hline
\end{tabular}

Sumber : Hasil Olahan Penulis

\section{h. Masterplan Kawasan Wisata Telaga Biru Cisoka}

Masterplan pada Kawasan Wisata Telaga Biru Cisoka terdiri atas beberapa area, seperti area komersial, area wisata air, area outbound dan olahraga, serta terdapat area tambahan berupa agrowisata. Kemudian terdapat area fasilitas sebagai penunjang bagi kebutuhan para pengunjung, seperti gazebo, foodcourt, toilet, parkir, mushola, dan sebagainya. Penambahan fasilitas tersebut bertujuan pula untuk meningkatkan kualitas dari pada Kawasan Wisata Telaga Biru Cisoka. Berikut dibawah ini merupakan peta rencana masterplan, sebagai berikut 


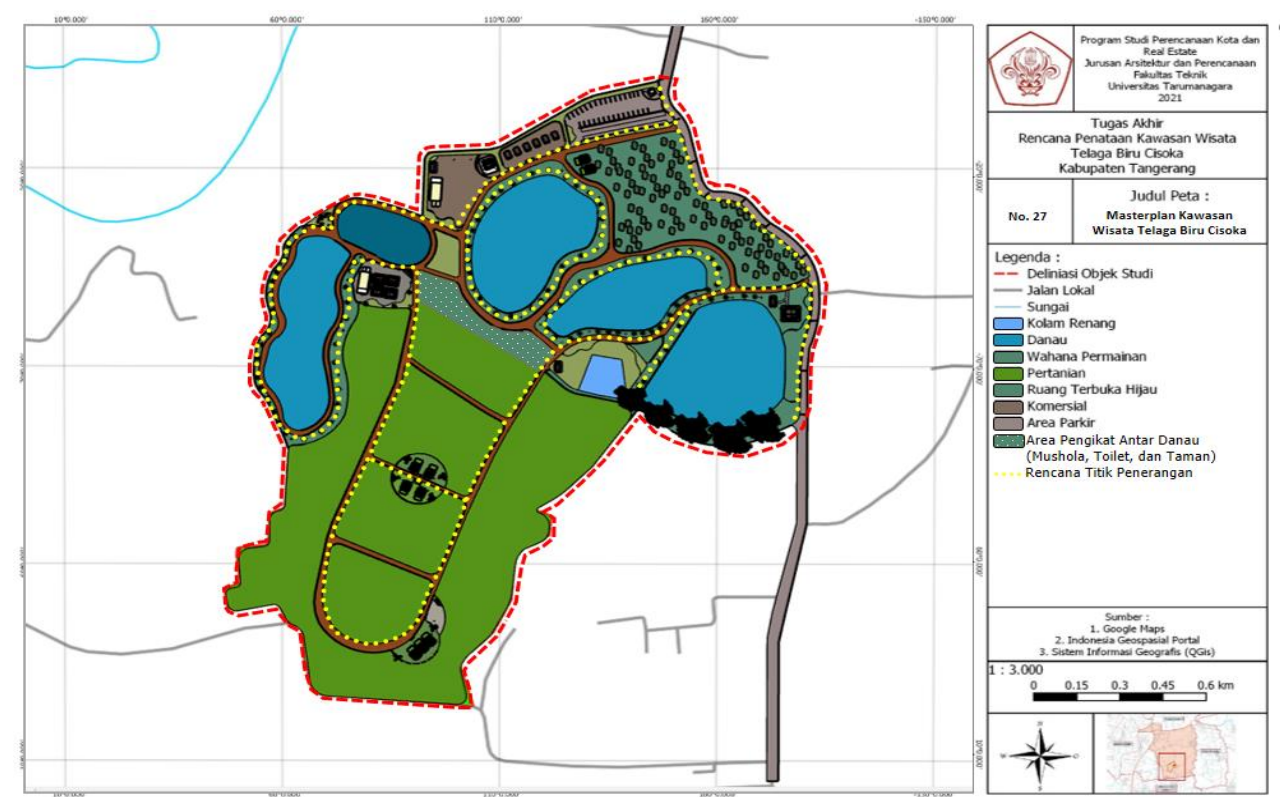

Gambar 4. Peta Rencana Masterplan Kawasan Wisata Telaga Biru Cisoka Sumber : Hasil Olahan Penulis

Tak hanya itu, dikarenakan terdapat danau $D$ yang terpisah dari danau lainnya, maka perlu adanya area pengikat untuk menarik pengunjung mengetahui lokasi danau $D$ tersebut. Area pengikat yang direncanakan berupa Mushola, Toilet, dan Taman, dan terdapat restaurant serta saung yang mengarah ke danau D.Berikut dibawah ini merupakan ilustrasi mengenai konsep masterplan yang direncanakan, sebagai berikut :

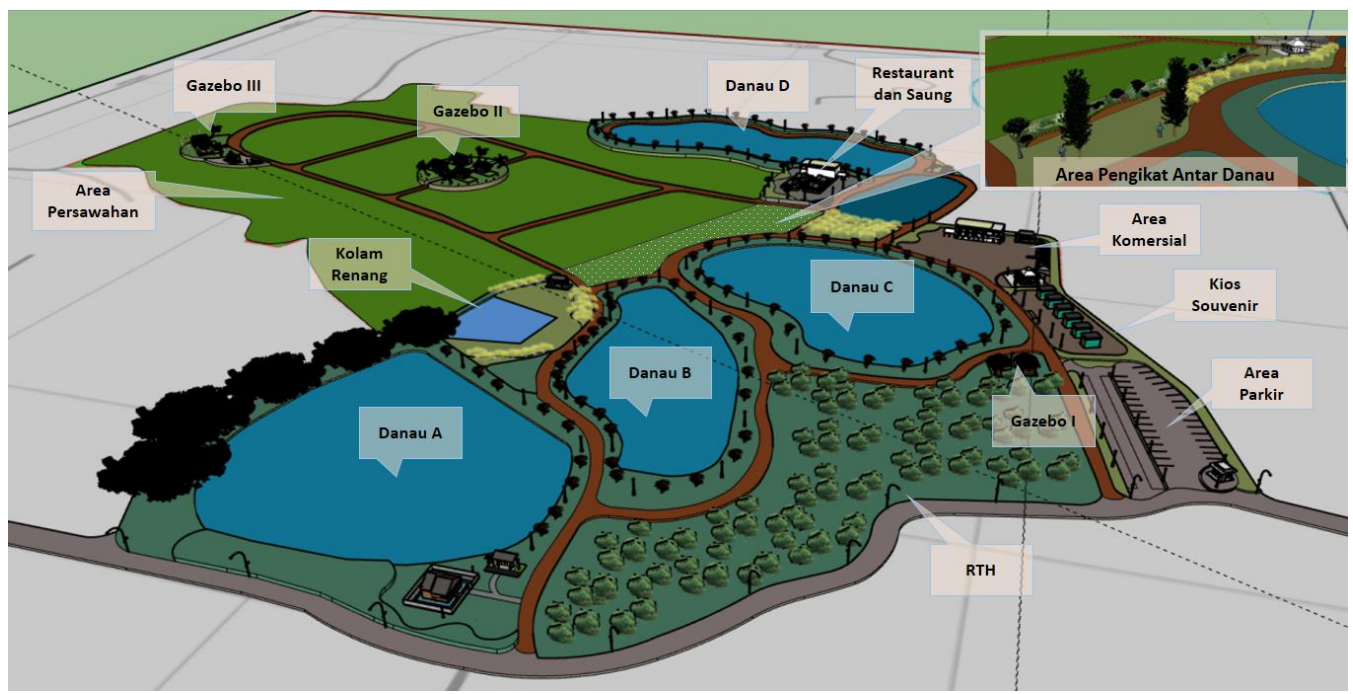

Gambar 5. Ilustrasi Masterplan Kawasan Wisata Telaga Biru Cisoka

Sumber : Hasil Olahan Penulis

\section{KESIMPULAN DAN SARAN}

\section{Kesimpulan}

Kawasan Wisata Telaga Biru Cisoka memiliki luas area wisata sebesar $10.84 \mathrm{Ha}$, yang merupakan salah satu destinasi wisata yang ada di Kabupaten Tangerang. Destinasi wisata ini merupakan area pasca galian pasir yang pernah dilakukan pada tahun 2006 sampai 2012. Setelah mencapai kedalaman yang kurang produktif, lalu galian pasir tersebut berubah menjadi genangan air. Kemudian Kawasan Wisata Telaga Biru dikembangkan secara individu oleh beberapa pihak, yakni pihak pemilik dan pengelola, kelompok Pokdarwis yang dibentuk 
oleh Pemerintah daerah, dan masyarakat setempat. Sehingga pengembangan yang dilakukan masih belum memiliki konsep wisata di dalamnya.

Berdasarkan hasil kondisi eksisting dan potensi yang ada pada Kawasan Wisata Telaga Biru Cisoka, maka pada perencanaan telah di analisis dan diusulkan memiliki konsep wisata yakni Wisata Alam dan Olahraga. Pemilihan konsep wisata ini terdiri atas, Wisata Agro yang menjadi potensi pengembangan, Wisata Air dan Rekreasi, serta Wisata Olahraga dengan konsep outbound dan fun bike. Tak hanya itu, perencanaan yang dilakukan terbagi menjadi 3 zona, yakni Zona air, Zona pertanian, dan zona Pendukung. Zona - zona tersebut akan disesuaikan dengan kondisi eksising pada Kawasan Wisata Telaga Biru Cisoka. Namun dalam rencana penataan tapak sendiri memiliki permasalahan dan kesulitan dalam perencanaannya, permasalahan utama yang ada pada Kawasan Wisata Telaga Biru Cisoka. Permasalahan yang paling mendesak atau utama, dijabarkan secara berurutan yakni pertama mempertahankan 4 Danau yang menjadi objek wisata, terdiri atas Danau A, Danau B, Danau C, Danau D. kemudian yang kedua yakni mempertahankan bentang alam dan lanskap, ketiga penggunaan lahan eksisting yang tidak sesuai dengan perlindungan alam, keempat pengolahan dan pembuangan jaringan drainase dan limbah, kelima penataan ulang terhadap fasilitas pendukung dan Infrastruktur, serta keenam kerjasama pengelolaan antar stakeholder.

Secara keseluruhan dari hasil penelitian dan perencanaan yang telah dilakukan pada Kawasan Wisata Telaga Biru Cisoka, maka hasil akhir berupa pembuatan rencana Masterplan pada Kawasan Wisata Telaga Biru Cisoka dan ilustrasi dalam masterplan tersebut yang dituangkan ke bentuk 3D. Sehingga fungsi daripada hasil akhir ini yakni, bertujuan untuk Kawasan Wisata Telaga Biru Cisoka menjadi lebih terawat dan tertata, serta permasalahan utama pada kawasan wisata dapat teratasi.

\section{Saran}

Dalam penelitian ini, penulis akan memberikan saran kepada para Stakeholder. Terdiri atas pemilik dan pengelola, Pokdarwis, masyarakat lokal, dan Pemerintah Daerah. Berikut dibawah ini merupakan saran yang diberikan oleh penulis kepada pihak terkait, sebagai berikut :

\section{Pemilik dan Pengelola}

Pemilik dan pengelola selaku pemilik Kawasan Wisata Telaga Biru Cisoka harus memiiki komunikasi yang baik terhadap komunitas pokdarwis dan masyarakat Desa Cisoka. Mengenai rencana penataan Kawasan Wisata Telaga Biru Cisoka. Tak hanya itu Pemilik dan pengelola harus ikut serta dalam merencanakan penataan Kawasan Wisata Telaga Biru Cisoka. Serta Pemilik dan Pengelola dapat membantu dalam mencari investor atau pihak ketiga yang ingin berinvestasi dalam perencanaan Kawasan Wisata Telaga Biru Cisoka.

\section{Pokdarwis}

Pokdarwis dapat melakukan komunikasi terhadap warga lebih baik kedepannya, agar apabila warga sekitar dapat merasakan dampak baik perekonomian dari Kawasan Wisata Telaga Biru Cisoka. Tak hanya itu, Pokdarwis memastikan warga lokal dapat ikutserta dalam perencanaan yang dilakukan pada Kawasan Wisata Telaga Biru Cisoka, serta dapat membantu masyarakat lokal dalam pelatihan khusus mengenai pariwisata.

\section{Masyarakat}

Adanya komunikasi terhadap masyarakat dengan pengelola dan pemiliki, komunitas pokdarwis Kawasan Wisata Telaga Biru Cisoka. Tak hanya itu, Masyarakat dapat dilatih khusus dan diberikan ilmu terkait keikutsertaan dalam rencana penataan yang akan 
dilakukan. Serta masyarakat diperbolehkan memberikan ide dan gagasan mengenai pembangunan dan penataan yang akan dilakukan.

\section{Pemerintah Daerah}

Adanya komunikasi terhadap pihak pemilik dan pengelola serta pihak pokdarwis dalam perencanaan Kawasan Wisata Telaga Biru Cisoka. Pemerintah daerah juga dapat Membantu dalam pelatihan khusus terkait wisata dan memberikan ilmu terkait perencanaan penataan yang akan direncanakan pada Kawasan Wisata Telaga Biru Cisoka. Serta membantu juga dalam promosi dan memperkenalkan Kawasan Wisata Telaga Biru Cisoka keluar daerah maupun provinsi lain, agar Kawasan Wisata Telaga Biru Cisoka lebih dikenal lagi oleh masyarakat lainnya.

\section{REFERENSI}

Apriani, D. W., Utomo, F. N., Wahyuni, S. E., Hardiyati, S. (2013). Evaluasi dan Perencanaan Kembali Bedung Sapon. Semarang : Jurnal Sipil.

Fuadi, N., Yanuar, J. P., Tarigan, S. D. (2016). Kajian Kebutuhan Air dan Produktivitas Air Padi. Jakarta : Jurnal Irigasi.

Harmani, E., \& Soemantoro, M. (2017). Kolam Retensi Sebagai Alternatif Pengendalian Banjir. Surabaya : Jurnal Teknik Sipil Unitomo.

Heywood, I., Cornelius, S., Carver, S. (2002). Geographical Information System, $2^{\text {nd }}$ Edition. Prentice Hall. London.

Mahara, S. (2011). Pemanfaatan Lahan Bekas Tambang untuk Tempat Rekreasi dengan Reklamasi di Sungai Binjai, Kecamatan Binjai Selatan. Medan : Jurnal Pendidikan Geografi, Jurnal Unimed.

Musanef. (2017). Manajemen Usaha Pariwisata di Indonesia. Jakarta : PT. Toko Gunung Agung.

Noviana, D. (2018). Analisis Daya Tampung Sungai Bedadung Menggunakan Metode Streeter Phelps. Studi Kasus: Desa Balung Kulon, Kecamatan Balung, Kabupaten Jember. Jember : Repository Universitas Jember.

Prachmayandini, R., Tarigan, S. D., Trisasongko, B. H. (2012). Penggunaan Citra Modis Sebagai Penduga Suhu Dalam Perhitungan Evapotranspirasi Dengan Metode Blaney-Criddle (Studi Kasus: Das Cimadur, Banten). Bogor : Jurnal Tanah Lingkungan.

Riskayana, A., A. K., Taufik, A. (2018). Partisipasi Masyarakat dalam Penataan Objek Wisata Alam. Yogyakarta : Jurnal Ilmu Pemerintahan.

Sabri, F. (2015). Pengelolaan Sumberdaya Kulong. Palembang : Citra Books.

Saiful, M. (2016). Manajemen Situ Sebagai Ruang Terbuka Biru Produktif Berbasis Masyarakat dan Berbasis Pengembang. Bogor : Jurnal Skripsi, Repository IPB.

Sujipta, I. Y. (2001). Agrowisata.Diktat Magister Manajemen Agribisnis. Bali : Universitas Udayana.

UNEP and WTO. (2005). Making Tourism More Sustainable: a Guide for Policy Makers. 
